\title{
REVISITING THE DETERMINANTS OF STUDENTS' SUCCESS IN CONDUCTING CREATIVITY PROGRAM
}

\author{
Sumaryanto $^{1 *}$, Tchello Kasse ${ }^{2}$, and Nur Hidayanto Pancoro Setyo Putro ${ }^{3}$ \\ ${ }^{1,3}$ Yogyakarta State University, Yogyakarta, Indonesia \\ ${ }^{2}$ University of Bamako, Bamako, Mali \\ *e-mail: sumaryanto@uny.ac.id
}

\begin{abstract}
Astract: This study investigated the determinants of students' success in completing creativity programs. A survey design was used in this study. A total of 351 respondents completed a survey on the factors that theoretically were related to students' creativity. Exploratory factor analysis (EFA) was then conducted to explore the factors that emerge as the correlates of students self-efficacy in completing the creativity program. Subsequently, confirmatory factor analysis (CFA) was performed to confirm the pattern proposed in the EFA. Finally, Structural Equation Modelling with Mplus was conducted to explore how the factors are related to students self-efficacy in completing the creativity program. The results showed that students' self-efficacy are strongly related to the role of their advisors, supports from their research community, and supports from the university. Comprehensive discussions on these factors are provided throughout this paper.
\end{abstract}

Keywords: students' creativity program, self-efficacy, confirmatory factor analysis

\section{IDENTIFIKASI FAKTOR-FAKTOR PENDUKUNG MAHASISWA DALAM PELAKSANAAN PROGRAM KREATIVITAS MAHASISWA}

\begin{abstract}
Abstrak: Penelitian ini bertujuan untuk mengidentifikasi faktor-faktor yang menentukan kesuksesan mahasiswa dalam melaksanakan Program Kreativitas Mahasiswa (PKM). Penelitian ini menggunakan desain penelitian survey. Sejumlah 351 mahasiswa terlibat dalam penelitian ini dengan mengisi survey tentang faktor-faktor yang secara teoritis terkait dengan kreatifitas mahasiswa. Analisis faktor eksploratori dilakukan untuk mengetahui faktor-faktor yang terkait dengan self-efficacy mahasiswa dalam melaksanakan PKM. Selanjutnya, analisis faktor konfirmatori dilaksanakan untuk mengkonfirmasi model yang telah di hasilkan dari analisis faktor eksploratori. Analisis terakhir yang dilakukan adalah Structural Equation Modelling dengan Mplus untuk mengetahui bagaimana faktor-faktor tersebut terkait dengan self-efficacy mahasiswa dalam melaksanakan PKM. Hasil penelitian menunjukkan bahwa selfefficacy mahasiswa terkait dengan peran dari pembimbingnya, dukungan dari organisasi penelitian mahasiswa, serta dukungan dari universitas. Faktor-faktor tersebut selanjutnya di diskusikan secara mendalam dalam artikel ini.
\end{abstract}

Kata Kunci: program kreatifitas mahasiswa, self-efficacy, confirmatory factor analysis

\section{INTRODUCTION}

In light of the disruptive era, it is becoming extremely difficult to ignore the existence of creativity as a central issue for success in both college and future career (Sternberg, Jarvin, \& Grigorenko, 2009;
Sternberg \& Lubart, 1995). These include the roles of creativity as an intangible resource that leads to problem solving (Runco, 1994), inspirations (Thrash, Maruskin, Cassidy, Fryer, \& Ryan, 2010), entrepreneurship (Ward, 2004), and 
innovation (Legrenzi, 2005). In other words, creativity can be said as one of the factors determining the success of university students.

In line with the importance of creativity, the Law of the Republic of Indonesia Number 12 Year 2012 Article 4 states that higher education has three main functions: 1) to develop the capability and to build the character and civilization of the nation for enhancing its intellectual capacity; 2) to develop academicians to be innovative, responsive, creative, skilful, competitive, and cooperative through the implementation of Tri dharma; and 3) to develop science and technology by taking into account and applying the value of humanities. In order to actualize those three functions, every university is required to equip its academicians and students with critical thinking skills which are manifested through research skills. These research skills are expected to help academicians and students conduct research to unearth, develop, and disseminate knowledge, technology, arts, and/or sports for the purposes of improving individual and social welfares supporting regional and national developments and answering global challenges.

One of the actualizations of the mission is through the establishment of students' research unit which houses students who want to gain and broaden their knowledge related to research. Through this community, students also learn to develop their research skills by conducting research studies manifested in the form of students' creativity programs. A students' creativity program is a program from the Directorate of Research and Community Service of the Ministry of Research, Technology, and Higher Education of the Republic of Indonesia to facilitate students to research, develop, and implement the knowledge and technology they learn. Students can participate in this program by writing a research proposal and/or a scientific paper. The selected proposals and/or papers will later be funded by the Ministry.
There are several factors influencing students' achievement especially in relation to the creativity programs. Preliminary study through interviews with creativity program teams showed that there were several factors that could presumably affect the ways of supervising the students and the students' creativity programs. The first factor found in the preliminary research was related to the ways of supervision by the advisor. The supervision from the advisor was not fully optimal due to the fact that students were confused both in writing the proposal and conducting their study. Furthermore, the roles of task forces from lecturers in each department and the creativity program task forces from each faculty were found not fully effective. The next factor was related to the information and facilities supports from the university. Then, it was also found that the roles of students' research community were immensely important in facilitating students during the process of creativity programs writing. In addition, a number of students in the initial study were found to be doubtful about their own ability in conducting the creativity programs.

Therefore, a study is needed that is aimed at identifying, verifying, and overcoming the problems specifically related to students' creativity programs which later could improve their achievement is needed. Considering the results of the preliminary study, this study sets out to identify the factors affecting students' achievement in creativity programs and the efforts needed to improve their achievement.

\section{Students Creativity Program}

University graduates are expected to have academic knowledge, skills of thinking, management skills, and communication skills. A lack of one of these four skills may lead to reduced quality of university graduates (Kemahasiswaan, 2018). To attain the four skills, university students need to synergize their mind (cognitive), emotion (affective), and skills 
(psychomotor) in order to be creative graduates. The mind deals with imagination, perception and reason (Currie \& Ravenscroft, 2002). Feelings are associated with emotions (Hershfield, Scheibe, Sims, \& Carstensen, 2013), aesthetics, and harmonization. Meanwhile, the psychomotor factor includes physical coordination, movement, and the motorskill area uses (Simpson, 1971). To help students reach the creative level, the three factors are strived to be optimal in an activity called the Students Creativity Program or, as well-known, the PKM (Kemahasiswaan, 2018).

PKM was held for the first time in 2001, namely after the implementation of the program restructuring in the Ditlitabmas Directorate General of Higher Education. PKM was developed to deliver students to reach the level of enlightenment of creativity and innovation based on the mastery of science and technology and high faith. In order to prepare themselves to be intellectual leaders, independent entrepreneurs and wise persons, students are given the opportunity to implement their abilities, expertise, attitude, responsibility, building teamwork, and developing independence through creative activities in their field of study.

Initially, there were five types of activities offered in PKM, namely research, entrepreneurship, community service, application of technology, and scientific writing. However, since January 2009, Ditlitabmas has managed 6 (six) PKMs. Student Writing Competition (KKTM), originally one function of the Academic Directorate in Management, has been delegated to Ditlitabmas. Because its nature is identical to PKM-I, KKTM is then managed together with PKM-I in the Scientific Writing PKM (Kemahasiswaan, 2018).

\section{Factors Supporting Individuals' Creativity}

Different research findings are found in the literature regarding factors supporting students' creativity projects. Sternberg (2006) propose six resources that contribute to students' interests and motivation in conducting creativity projects. These include intellectual abilities, knowledge, styles of thinking, personality, motivation, and environment. In addition, Ginting (2013) state that both motivation to self-actualization and motivation to share knowledge have significant influence on students' interests in writing and publishing their project. On the other hand, motivation factors to gain reward and to show their existence do not have any significant influence on students' interests in writing and publishing projects.

Other psychological factors believed to be influencing people's intention to do something creative have been explored in several studies. One of these psychological factors is self-efficacy. Early definition of self-efficacy is provided by Bandura (1997) as "personal judgments of one's capabilities to organize and execute courses of action to attain designated goals, and he sought to assess its level, generality, and strength across activities and contexts". Its measurement generally focuses on performance capabilities rather than on personal qualities through either psychological or physical characteristics. This psychological construct has been long believed as a vital condition for creative productivity and the acquisition of new knowledge (Tierney \& Farmer, 2002) since it influences individuals' intention to engage in specific behavior (Bandura \& Wessels, 1994) and to search of certain tasks (Bandura \& Schunk, 1981). In addition, self-efficacy is also claimed to be a key component in individual creative actions (Ford, 1996). Tierney and Farmer (2002) investigates how workers' selfefficacy is related to their belief that they can be creative in completing their works. The findings show that the supervisor is one key role who interferes with the workers' self-efficacy in work roles. These propositions are in line with a study conducted by Oldham and Cummings 
(1996) that positive supervision is related to employers' creativity at work. Other studies by Liu, Liao, and Loi (2012); Fenge (2012) also reveal the roles of supervisors in employees' creativity. These studies may indicate that supervising lecturers or advisors also interfere with students' intention in conducting creativity programs.

Another factor that has been claimed to interfere with individuals' creativity is in the form of supports from the community or the environment where the individuals live (Rigolizzo \& Amabile, 2015). It is believed that "an environment that supports the process of creativity, rather than the outcome, allows people to practice and learn both from and for the creative process" (Rigolizzo \& Amabile, 2015, p. 62). Further, Solomon (2018) suggests five factors that influence individuals' creativity; namely facilitation, controlling information, prioritization, back-channel network, and shortcuts. This may indicate that supports from students' research community or union, facilitation from the university, and the availability of information are the correlates of students' creativity in conducting students' creativity programs.

To sum up, although extensive research has been carried out on factors affecting creativity, no single study exists which examines the factors contributing to students' success in conducting students' creativity program (PKM) in Indonesian setting. The present study is aimed at revisiting the potential factors which may interfere with students' success in conducting creativity programs.

\section{METHOD}

\section{Research Sample}

This study was a survey research of the quantitative approach. The population of the study included all students conducting creativity programs in a public university in Yogyakarta Special Province, Indonesia, as described in the introduction above. Every student in the population had an equal chance of being selected in the sample in the study. The participants were drawn from the population since they were homogeneous and relatively small in number. A total of 351 university students participated in the study.

\section{Instrument}

The present study was conducted from July to December 2017. The data were collected using a questionnaire of 46 items. The items represented several factors identified to be the correlates of students' creativity namely students' self-efficacy (7 items), supports from the advisors (7 items), supporting facilities from the university ( 7 items), supports from the students' research union (7 items), supports from the student affairs staff ( 7 items), and the availability of information supports from the university ( 7 items). Respondents were to rate on a five-point rating scale, ranging from strongly disagree (1) to strongly agree (5).

\section{Data Analysis Technique}

The data gathered from the data collection were analysed using an exploratory factor analysis (EFA) and confirmatory factor analysis (CFA) as the main data analysis techniques in the study. In addition, the structural equation modelling (SEM) was used to investigate the relationships among the aforementioned factors. Several criteria were used for analyzing and interpreting the results of EFA. First, items were retained in the study if the factor loading for each item was higher than .30; second, items were retained if they were significantly loaded in one factor (Field, 2009). Additionally, the criteria for being used in the CFA and SEM included:

- $x^{2} / \mathrm{df} \leq 1.3$

- $\mathrm{RMSEA} \leq .50$

- $\mathrm{SRMR} \leq .80$

- $\quad \mathrm{CFI} \geq .90$, and 
- $\quad$ TLI $\geq .90$ (Wang \& Wang, 2012)

\section{Pilot Testing}

Prior to the actual data collection, a pilot study was conducted to assess the usability and readability of the questionnaire. Fifteen students took part in the pilot study to give judgements whether each item in the questionnaire was readable and unambiguous. The results of the pilot test showed that the overall questionnaire was readable and no item was ambiguous.

\section{FINDINGS AND DISCUSSION}

This section describes the findings of the study and discussion of the findings. This includes results from the factor analyses investigating factors supporting students' science and creativity programs, and the relationships among those factors.

\section{FINDINGS}

\section{Results of the Exploratory Factor Analysis}

Results of the exploratory factor analysis on the Version-22 SPSS software showed that loadings from some factors differed and were ready to be interpreted. All the factor loadings from all variables were substantial in size. The exploratory factor analysis showed that 18 items were retained from the initial set of 46 items with factor loadings ranging from .395 to .992 . In other words, from the initial set of 46 items, 18 items empirically represented the factors influencing students' creativity programs. Table 1 shows the summary of the exploratory factor analysis results including the factors and their loadings.

\section{Factor Interpretations from the Results of EFA}

As mentioned earlier, items with factor loadings higher than .30 were considered significant with $\alpha=.05$ (Field, 2009). Therefore, only those with factor loadings higher than .30 were retained. As Table 1. Results of Exploratory Factor Analysis (Pattern Matrix ${ }^{a}$ ) can be seen in Table 1, the 18 items converged into five different factors with three or four items in each factor. The interpretation of each factor is discussed as follows.

Based on the aforementioned criteria, all the factor loadings in Table 1 were considered as significant as they were greater than .30. Factor one consists of four items ranging from .766 to .922 . Then, among the four items, item 1 shows the highest factor loading of all, i.e., .922. Likewise, factor two consists of four items ranging from .582 to .939 . Item 5 was the highest with a factor loading of .939. Factor three, on the other hand, only consists of three items. The loadings for this factor range from .627 to .874 with the highest factor on item 9. Similarly, factor four consists of three items ranging from .600 to 992. Item 12 was the one with the highest factor loading from factor one to factor five. Finally, factor five has four significant items for which the factor loadings range from .395 to .841 .

\section{Factor or Construct Labelling}

After the five factors, which contain several variables or items, were formed, they were labelled based on the characteristics of each item represented in each factor. The items in the first factor included a number of questions asking about students' knowledge and capability in conducting science or creativity programs. The key term for this factor was the students' belief about their capability. Therefore, after generalizing the four items in this factor, the researchers labelled it as Students' Self-efficacy.

The second factor contains four items related to the communication between the students and the advisors of creativity programs in the departments and faculties and also the supervision given by the advisors. Therefore, this factor was labelled Support from the Creativity Program Advisor. 


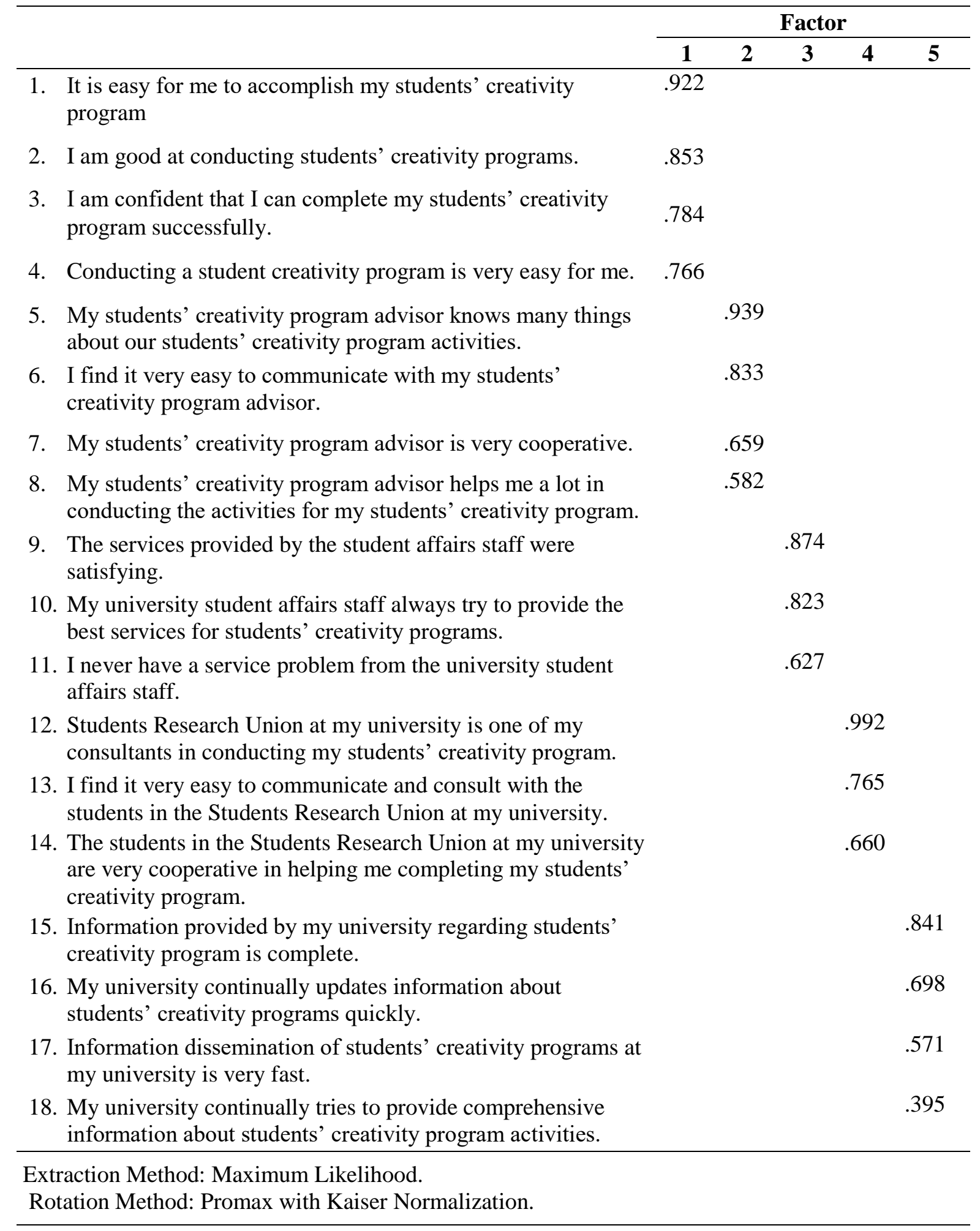

a. Rotation converged in 5 iterations.

Factor three contains items related to the support for the students' creativity programs, approval process, and administration from the campus. This factor, then, was labelled Approval and

\section{Administration Support from the University.}

The three items grouped in factor five were those related to the support from the students' research unit or students' research 
community. The supports specifically consisted of communication and consultation supports from the community in relation to conducting creativity programs. Therefore, this factor was labelled Support from the Research Community.

The last factor contained four items related to the ease of accessing information about creativity programs by the university. Therefore, the researchers labelled this factor Information Support from the University.

Subsequent to the interpretation and labeling of the five factors, the researchers assessed the construct validity of the five factors by conducting confirmatory factor analysis (CFA). This was conducted to confirm whether the results from the exploratory factor analysis came out as hypothesized.

\section{Results of Confirmatory Factor Analysis}

The final assessment on the five factors resulted in the exploratory factor analysis was conducted using MPlus Version-7 (Muthen \& Muthen, 1998-2012). The results from the data analyses showed that the constructs assessed in the confirmatory factor analysis showed an excellent fit data $\left(x^{2}=146.635 ; \mathrm{df}=125\right.$; $x^{2} / \mathrm{df}=1.3 ; \mathrm{RMSEA}=.047 ; \mathrm{SRMR}=.064 ;$ $\mathrm{CFI}=.963$; and $\mathrm{TLI}=.954)$. The criteria for good fit indices used to confirm whether the factorial structures fit the model include:

- $x^{2} / \mathrm{df} \leq 1.3$

- $\mathrm{RMSEA} \leq .50$

- $\mathrm{SRMR} \leq .80$

- $\quad \mathrm{CFI} \geq .90$, and

- $\quad$ TLI $\geq .90$ (Wang \& Wang, 2012)

Based on these criteria, the 5-factor model was considered to be the best. The summary of the CFA results including the factor labels, items, factor loadings, and reliability of each factor is presented in in Table 2. This table shows that after being assessed by the confirmatory factor analysis, the five factors are fit for the model of the present study. Most of the factor loadings from each factor are relatively high. Factor loadings from the first factor range from .623 to .925 . Similarly, the items in the second factor show relatively high factor loadings ranging from .792 to .889 .

Then, factor three consists of items with factor loading ranging from .659 to 987. Next, high factor loadings are also found in factor four which range from .724 to .906 . Likewise, all the items in factor five range in high factor loadings from .633 to .786. Therefore, all the factor loadings in the CFA are substantial in size. The high factor loadings contribute to the reliability coefficient from each factor as well. As can be seen from the table, the Cronbach's Alpha from the five factors range from .753 to .899 which show a reasonably high value of reliability coefficient.

\section{Results of Structural Equation Modelling}

After the five factors were confirmed by the confirmatory factor analysis, the next analysis was to investigate whether the factors were correlated with each other. To identify the relationships among those factors, an analysis of structural equation

modelling using MPlus Version-7 was conducted. The criteria for good fit indices used to confirm whether the factorial structures fit the model include:

- $x^{2} / \mathrm{df} \leq 1.3$

- $\mathrm{RMSEA} \leq .50$

- $\mathrm{SRMR} \leq .80$

- $\quad \mathrm{CFI} \geq .90$, and

- $\quad$ TLI $\geq .90$ (Wang \& Wang, 2012) 
Table 2. Summary of the Confirmatory Factor Analysis Results: Factors, Items, and Reliability of Each Scale

\begin{tabular}{|c|c|c|c|c|c|}
\hline Items & $\begin{array}{c}\text { Self- } \\
\text { efficacy }\end{array}$ & $\begin{array}{l}\text { Supports from } \\
\text { the Advisors }\end{array}$ & $\begin{array}{c}\text { Approval and } \\
\text { Administration } \\
\text { Supports from the } \\
\text { Student Affairs Staff }\end{array}$ & $\begin{array}{l}\text { Supports } \\
\text { from the } \\
\text { Research } \\
\text { Community }\end{array}$ & $\begin{array}{l}\text { Information } \\
\text { Supports } \\
\text { from the } \\
\text { University }\end{array}$ \\
\hline Item 1 & .690 & & & & \\
\hline Item 2 & 925, & & & & \\
\hline Item 3 & .802 & & & & \\
\hline Item 4 & .632 & & & & \\
\hline Item 5 & & .815 & & & \\
\hline Item 6 & & .889 & & & \\
\hline Item 7 & & .840 & & & \\
\hline Item 8 & & .792 & & & \\
\hline Item 9 & & & .659 & & \\
\hline Item 10 & & & .875 & & \\
\hline Item 11 & & & .987 & & \\
\hline Item 12 & & & & .724 & \\
\hline Item 13 & & & & .806 & \\
\hline Item 14 & & & & .906 & \\
\hline Item 15 & & & & & .768 \\
\hline Item 16 & & & & & .680 \\
\hline Item 17 & & & & & .575 \\
\hline Item 18 & & & & & .633 \\
\hline Alpha & .834 & .899 & .873 & .825 & .753 \\
\hline
\end{tabular}

These criteria were the same criteria used in the confirmatory factor analysis. The model tested in the structural equation modelling (SEM) analysis investigated whether the five factors resulted in the confirmatory factor analysis including: Self-efficacy (F1); Supports from the
Advisors, Departments and Faculties (F2); Approval and Administration Spports from the University (F3); Supports from the Research Community (F4); and Information Supports from the University (F5) were correlated with each other. The results of the SEM analyses for the five factors are displayed in Figure 1. 


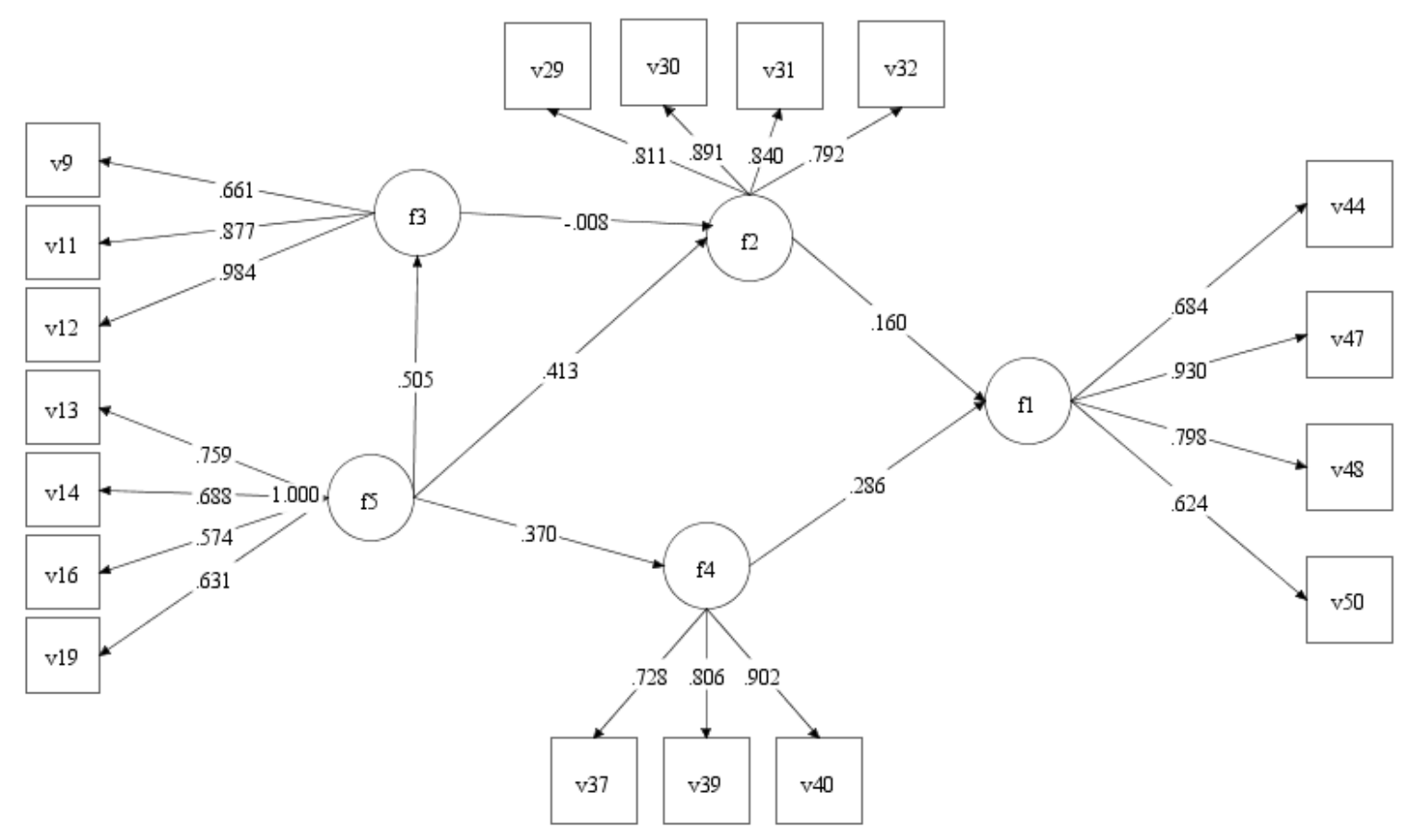

Figure 1. The Results of the SEM Analysis for the Five Factors

Note: F1: Self-efficacy; F2: Supports from the Advisors; F3: Approval and Administration Supports from the Student Affairs Staff; F4: Supports from the Research Community; F5: Information Supports from the University

Figure 1 shows that the five factors that have been identified by THE exploratory and confirmatory factor analyses ARE correlated each other. The relationships among those factors are explained as follows:

a. Students' self-efficacy in completing creativity programs or their selfconfidence to be able to complete the creativity programs (F1) is influenced directly by the Supports from the Advisors (F2) $(\beta=.544, p<.01)$; and Supports from Students' Research Community $(\mathrm{F} 4)(\beta=.286, p<.01)$;

b. Supports from the Advisors (F2) is influenced by Supports from Students' Research Community (F3) $(\beta=.334, p$ $<.01)$; and Information Supports from the University (F5) $(\beta=.413, p<.01)$;

c. Supports from the Research Community (F4) is influenced by the Information Supports from the University (F5) $(\beta=.370, p<.01)$; and d. Approval and Administration Support from the University (F3) is influenced by the Information Supports from the University (F5) $(\beta=.505, p<.01)$.

The relationships among factors supporting students' in completing the creativity programs show the importance of supports from the university to improve the students' capability in writing and conducting students' creativity programs. Nevertheless, the coefficient correlations among those factors can presumably be given more attention by all the university parties since the coefficient values may be increased.

\section{DISCUSSION}

This study aims to identify the factors affecting students' achievement in creativity programs and the efforts needed to improve their achievement. The results of exploratory factor analysis (EFA) and confirmatory factor analysis (CFA) have 
demonstrated that there are five factors supporting students' achievement in creativity programs. Those five factors are: self-efficacy; supports from the advisors, departments, and faculties; approval and administration support from the university; supports from the research community; and information supports from the university. These results are in line with several studies claiming that students' success in the students' creativity programs are influenced by both internal and external factors, e.g., (Sternberg, 2006). They include intellectual abilities, knowledge, styles of thinking, personality, motivation, and environment.

The following sub-section provides further discussion for each factor supporting students' achievement in the creativity program.

\section{Self-efficacy}

Students' self-efficacy in conducting the creativity programs is immensely important. Self-efficacy is a result of a cognitive process in the forms of decision, belief, or reward on how far someone can predict his or her capability in accomplishing a certain task with satisfactory results (Bandura \& Wessels, 1994). Self-efficacy does not directly correlate with people's abilities; yet, it correlates with their belief about what they can do with the abilities they have, no matter how small it is (Pajares \& Johnson, 1994). Self-efficacy emphasizes on the people's self-belief to face unpredictable conditions in the near future. Students with self-efficacy believe that they will be able to conduct research and creativity programs more readily than those who do not. On the other hand, those with low self-efficacy tend to judge themselves incapable of doing any job assigned to them. This is in line with Saeid and Eslaminejad (2016) study which reveals that self-efficacy and academic motivation have a strong impact on increasing students' creative programs.
This indicates that to create students with good knowledge and skills in research, it is suggested that they be given supports or motivation to conduct the creativity programs so that they will have outlets through which their creative and innovative ideas can be expressed (Saeid \& Eslaminejad, 2016).

In order to improve students' selfefficacy, the university should provide training about the urgency of creativity programs to the freshmen so that they can possibly develop their interest in students' creativity programs from the beginning. Furthermore, a substantial and considerable reward is also needed for those with outstanding achievement in the students' creativity programs; for instance, the programs which are selected to compete in the National Student Science Week and win gold medals in which later can be acknowledged as equal to an undergraduate thesis.

\section{Roles of advisors}

The present study has also demonstrated that the roles of the advisors are in the moderate category $(\beta=.286, p<$ $.01)$. The roles of the advisors in the creativity programs are important. This is in line with the results of studies by Oldham and Cummings (1996); Liu et al. (2012); Fenge (2012); Suwarna (2005). Advisors roles are not only to guide the students so that the programs will go as planned, but also to help them to access the facilities from campus, give solution or justification for the problems they face, motivate the students, and monitor the programs periodically.

Considering the importance of the roles of advisors, an effort is needed to improve their understanding on the creativity programs and reviewing techniques on potential problem analyses by proposing creative ideas and using various strategic choices. Therefore, to improve students' achievement, lecturers should understand and carry out their duties as the advisors such as: 
a. reading and comprehending the guide books for the students' creativity program and national student science week;

b. guiding students' of the programs with high creativity and innovation values;

c. supervising, making suggestions, and evaluating the students during the process of creativity programs completion;

d. guiding the students in both the monitoring and evaluation process, and in the national student science week;

e. correcting and making suggestions on students' progress reports, final reports, posters, and journals.

With the intention of improving the advisors' roles, several actions can be done by the university such as providing training of trainers (ToT) for the lecturers. In this activity, the university requires that every lecturer supervise at least one program in one year. Another action can be providing incentives for the lecturers whose students produce a notable achievement.

\section{Roles of students' research unit}

To improve their effectiveness in completing creativity programs, students should possess the passion and motivation to gain knowledge and skills for conducting research and creativity programs by joining the students' research community in campus. Students normally find it easier to communicate with their peers, including in completing their creativity project. This is in line with findings from $\mathrm{Liu}, \mathrm{Lu}, \mathrm{Wu}$, and Tsai (2016) in the sense that supports from peer review processes may help students to build a sophisticated level of reflection upon their creativity. Furthermore, another study by Hughes, Gillespie, and Kail (2010) supports the findings from this study in the sense that peers provide significant supports in the improvent of students' project achievement.

This indicates that universities need to facilitate students with a students' research unit which aims to facilitate students to gain information, knowledge, and skills to conduct research. However, the results of the present study show that the roles of students' research unit have not been fully effective in facilitating students to write research proposals in the form of students' creativity program $(\beta=.286, p<$ $.01)$. Therefore, universities should conduct strategic planning to optimise the roles of students' research unit or research community; for example, by conducting Student Science Week prior to students' creativity program proposals so that the quality and quantity of students' programs can improve.

\section{Roles of the university}

The results obtained in the present study show that information and facilities supports from university, specifically from the Reasoning Division of the Department of Student Affairs, can be improved $(\beta=$ $.370, p<.01)$ and $(\beta=.505, p<.01)$. This suggests that university strategic planning should aim to improve the roles of the university to provide information and supporting facilities for students' creativity programs. This is in line with the findings from Small (2014) which suggests that educational institutions must make many opportunities available to students so that they can create, innovate, and explore their knowledge. The roles of the university are undeniably crucial since any information from the Directorate General of Learning and Student Affairs, Ministry of Research, Technology, and Higher Education, including the one related to students' creativity program, is directly given to the university. Consequently, the university has the alternatives to:

a. give a comprehensive training for students' creativity program centres as the front line that provide information and services for university students;

b. provide training of trainer (ToT) for the advisors and task forces from each department so that they can provide university students with detailed information in relation to the creativity programs; 
c. provide training on students' creativity programs from the beginning; i.e. for freshmen.

\section{CONCLUSION}

This survey research set out to investigate factors influencing students' achievement in the students' creativity programs. This five-month study has provided additional evidence with respect to the key factors that have affected students' creativity programs. These include: (a) self-efficacy or students' selfbelief that they are able to conduct a good creativity program; (b) supports from the advisors, departments, and faculties; (c) approval and administration support from the university; (d) supports from the students' research community; and (e) information supports from the university.

As a result of investigations of these factors, suggestions are proposed for the university to improve the quality and quantity of students' creativity programs. These include the following.

a. In order to improve students' selfefficacy, universities should provide training about the urgency of creativity programs to the freshmen so that they can possibly develop their interest in students' creativity programs from the beginning. Furthermore, a substantial reward is also offered to those with outstanding achievement in students' creativity programs; for example, the programs that are selected to compete in the National Student Science Week and win gold medals which later can be acknowledged as equal to an undergraduate thesis.

b. With the intention of improving the advisors' roles, several actions can be done by the university. Such actions can be providing training of trainers (ToT) for the lecturers, requiring every lecturer to supervise at least one program in one year, and providing incentives for the lecturers whose students attain a notable achievement. c. Student Science Week for universities students can be conducted prior to students' creativity program proposal writing. This is expected to be able to improve the quality and quantity of the students and to optimise the roles of the students' research unit.

d. The university provides comprehensive training for students' creativity program centres. This is due to the importance of the centres as the front line that provide information and services for universities students.

e. Each department is providing with training of trainer (ToT) for advisors and task forces. This will enable the department and advisors to provide detailed information for universities students in relation to the creativity programs;

f. Training on students' creativity programs can be given from the beginning, i.e. for freshmen.

\section{REFERENCES}

Bandura, A. (1997). Self-efficacy: The exercise of control. New York, NY: W H Freeman.

Bandura, A., \& Schunk, D. H. (1981). Cultivating competence, selfefficacy, and intrinsic interest through proximal self-motivation. Journal of personality and social psychology, $\quad 41(3), \quad 586$. doi:10.1037/0022-3514.41.3.586.

Bandura, A., \& Wessels, S. (1994). Selfefficacy. In V. S. Ramachaudran (Eds.), Encyclopedia of Human Behaviour (pp. 71-81). New York, NY: Academic Press.

Currie, G., \& Ravenscroft, I. (2002). Recreative minds: Imagination in philosophy and psychology. New York, NY: Clarendon Press.

Fenge, L.-A. (2012). Enhancing the doctoral journey: The role of group supervision in supporting 
collaborative learning and creativity. Studies in Higher Education, 37(4), 401-414.

doi:10.1080/03075079.2010.520697.

Ford, C. M. (1996). A theory of individual creative action in multiple social domains. Academy of Management review, 21(4), 1112-1142. doi:10.5465/amr.1996.9704071865.

Ginting, D. A. (2013). Faktor-faktor yang mempengaruhi minat mahasiswa akuntansi dalam menulis dan mempublikasikan karya ilmiah (Studi kasus pada tiga perguruan tinggi negeri di Kota Malang). Jurnal Ilmiah Mahasiswa FEB, 2(1).

Hershfield, H. E., Scheibe, S., Sims, T. L., \& Carstensen, L. L. (2013). When feeling bad can be good: Mixed emotions benefit physical health across adulthood. Social psychological and personality science, 4(1), 54-61. doi:10.1177/1948550612444616.

Hughes, B., Gillespie, P., \& Kail, H. (2010). What they take with them: Findings from the peer writing tutor alumni research project. The Writing Center Journal, 30(2), 12-46.

Kemahasiswaan, D. (2018). Pedoman Program Kreativitas Mahasiswa 2018. Jakarta: Kemenristek Dikti.

Legrenzi, P. (2005). Creativity and innovation. Icon, 39(051), 256011.

Liu, C. C., Lu, K. H., Wu, L. Y., \& Tsai, C. C. (2016). The impact of peer review on creative self-efficacy and learning performance in Web 2.0 learning activities. Journal of Educational Technology \& Society, 19(2), 286297.
Liu, D., Liao, H., \& Loi, R. (2012). The dark side of leadership: A three-level investigation of the cascading effect of abusive supervision on employee creativity. Academy of Management journal, 55(5), 1187-1212. doi:10.5465/amj.2010.0400. 1187.

Oldham, G. R., \& Cummings, A. (1996). Employee creativity: Personal and contextual factors at work. Academy of Management journal, 39(3), 607634. doi:10.5465/256657.

Pajares, F., \& Johnson, M. J. (1994). Confidence and competence in writing: The role of self-efficacy, outcome expectancy, and apprehension. Research in the Teaching of English, 28(3), 313-331.

Rigolizzo, M., \& Amabile, T. (2015). Entrepreneurial creativity: The role of learning processes and work environment supports. The Oxford handbook of creativity, innovation, and entrepreneurship, 61-78. doi:10.1093/oxfordhb/97801999276 78.013.0018.

Runco, M. A. (1994). Problem finding, problem solving, and creativity. New Jersey, NJ: Greenwood Publishing Group.

Saeid, N., \& Eslaminejad, T. (2016). Relationship between student's selfdirected-learning readiness and academic self-efficacy and achievement motivation in students. International Education Studies, 10(1), 225. doi:10.5539/ies.v10n1p225.

Simpson, E. (1971). Educational objectives in the psychomotor domain. Behavioral objectives in curriculum development: Selected readings and bibliography, 60(2). 
Small, R. V. (2014). The Motivational and Information Needs of Young Innovators: Stimulating Student Creativity and Inventive Thinking. School Library Research, 17.

Solomon, Y. (2018). 5 Ways Administrative Assistants Can Help Creativity In A Major Way. Retrieved from https://www.inc.com/yoramsolomon/4-ways-administrativeassistants-can-help-creativity-in-amajor-way.html.

Sternberg, R. J. (2006). The nature of creativity. Creativity Research Journal, 18(1), 87-98. doi:10.1207/s15326934crj1801_10.

Sternberg, R. J., Jarvin, L., \& Grigorenko, E. L. (2009). Teaching for wisdom, intelligence, creativity, and success: Corwin Press.

Sternberg, R. J., \& Lubart, T. I. (1995). Defying the crowd: Cultivating creativity in a culture of conformity: Free Press.
Suwama, S. (2005). Pengembangan kompetensi kreatif mahasiswa PGTK lewat menggambar. Cakrawala Pendidikan, (1). Doi: 10.21831/cp.v0i1.4713.

Thrash, T. M., Maruskin, L. A., Cassidy, S. E., Fryer, J. W., \& Ryan, R. M. (2010). Mediating between the muse and the masses: Inspiration and the actualization of creative ideas. Journal of personality and social psychology, $\quad 98(3), \quad 469$. doi: $10.1037 / \mathrm{a} 0017907$.

Tierney, P., \& Farmer, S. M. (2002). Creative self-efficacy: Its potential antecedents and relationship to creative performance. Academy of Management journal, 45(6), 11371148. doi:10.2307/3069429.

Wang, J., \& Wang, X. (2012). Structural equation modeling: Applications using Mplus. West Sussex: John Wiley \& Sons.

Ward, T. B. (2004). Cognition, creativity, and entrepreneurship. Journal of business venturing, 19(2), 173-188. doi:10.1016/S0883-9026(03)000053. 